\title{
Application of a methodology with georeferencing in the biological study of fish in the area of influence of a dam in the amazon region
}

Aplicação de uma metodologia com georreferenciamento no estudo biológico de peixes na área de influência de um barramento na região amazônica

Aplicación de una metodología con georreferenciación en el estudio biológico de peces en el área de influencia de un reservorio en la región amazónica

Fábio Alexandre Travassos

ORCID: https://orcid.org/0000-0002-2892-0904 Universidade Federal do Pará, Brazil E-mail: profdr.travassos@gmail.com

Miguel Petrere Junior

ORCID: https://orcid.org/0000-0003-2000-6699 Universidade Federal do Pará, Brazil

E-mail: mpetrerejr@gmail.com

\begin{abstract}
The continuous interference of human activities in continental aquatic systems results in direct and indirect impacts, with consequences for water quality, aquatic biota and the dynamics of water resources. In this context, the Tucuruí Hydroelectric Power Plant (HPP) acquired relatively importance, as it was the first large dam carried out in the Amazon, in the 1980s, presenting important technical/economic results to justify the environmental costs associated with the project. The objective of this study was to apply a new methodology to represent through maps georeferencing biological information and evaluate the impact of the dam on the following fish species, which have different physiologies and taxonomies, in addition to not having much biological information about the species: Botinho (Hassar wilderi, Doradidae), Mandubé (Ageneiosus ucayalensis, Auchenipteridae), Sardinha Papuda (Triportheus trifurcatus, Characidae) and Uéua Cachorrinho (Acestrorhynchus falcirostris, Acestrorhynchidae). The condition factor related to the relationship between the individual's weight and body length, which derives from an expansion of the cubic law of living beings, being very important in ecological studies, even though they depend on simple to the most complex scientific methods, to estimate this bodily condition. Furthermore, this biological parameter influenced by environmental conditions and characteristics, due to food availability and ecological relationships in the environment. This information can support an adequate fisheries management, as there is an integration of fisheries biology and the characteristics of the environment in which they live. Thus, the methodology applied in this study was successful in its application proposal.
\end{abstract}

Keywords: Tropical ichthyofauna; Conservation and development; Condition factor; Neotropical reservoir; Fisheries biology.

\section{Resumo}

A contínua interferência das atividades humanas nos sistemas aquáticos continentais resulta em impactos diretos e indiretos, com consequências para a qualidade da água, a biota aquática e a dinâmica dos recursos hídricos. Neste contexto, a Usina Hidrelétrica (UHE) de Tucuruí relativamente adquiriu importância por ter sido o primeiro grande barramento realizado na Amazônia, na década de 80, apresentando resultados técnicos/econômicos importantes para justificar os custos ambientais associados ao empreendimento. O objetivo deste estudo foi aplicar uma nova metodologia para representar através de mapas georeferenciando as informações biológicas e avaliar o impacto do barramento sobre as seguintes espécies de peixes, que possuem fisiologias e taxonomias distintas, além de não haver muitas informações biológicas das espécies: Botinho (Hassar wilderi, Doradidae), Mandubé (Ageneiosus ucayalensis, Auchenipteridae), Sardinha Papuda (Triportheus trifurcatus, Characidae) e Uéua Cachorrinho (Acestrorhynchus falcirostris, Acestrorhynchidae). $\mathrm{O}$ fator de condição está relacionado à relação entre o peso do indivíduo e o comprimento do corpo, que deriva de uma expansão da lei cúbica dos seres vivos, sendo muito importante em estudos ecolócicos, ainda que dependam de métodos científicos simples até os mais complexos, para se estimar esta condição corporal. Ainda, este parâmetro biológico é influênciado pelas condições e características 
ambientais, devido a disponibilidade de alimentos e relações ecológicas no ambiente. Desta maneira, estas informações podem subsidiar um manejo pesqueiro adequado, pois existe uma integração da biologia pesqueira e as características do ambiente onde vivem. Assim, a metodologia aplicada neste estudo apresentou exito na proposta de aplicação.

Palavras-chave: Ictiofauna trotical; Conservação e desenvolvimento; Fator de condição; Reservatório neotropical; Biologia pesqueira.

\section{Resumen}

La interferencia continua de las actividades humanas en los sistemas acuáticos continentales tiene como resultado impactos directos e indirectos, con consecuencias para la calidad del agua, la biota acuática y la dinámica de los recursos hídricos. En este contexto, la Central Hidroeléctrica Tucuruí (CHE) adquirió relativa importancia al ser la primera gran represa realizada en la Amazonía, en la década de 1980, presentando importantes resultados técnicoeconómicos para justificar los costos ambientales asociados al emprendimiento. El objetivo de este estudio fue aplicar una nueva metodología para representar a través de mapas georreferenciando información biológica y evaluar el impacto de la presa sobre las siguientes especies de peces, las cuales tienen diferentes fisiologías y taxonomías, además de no contar con mucha información biológica sobre la especie: Botinho (Hassar wilderi, Doradidae), Mandubé (Ageneiosus ucayalensis, Auchenipteridae), Sardinha Papuda (Triportheus trifurcatus, Characidae) and Uéua Cachorrinho (Acestrorhynchus falcirostris, Acestrorhynchidae). El factor condición está relacionado con la relación entre el peso del individuo y la longitud corporal, que deriva de una expansión de la ley cúbica de los seres vivos, siendo muy importante en los estudios ecológicos, aunque dependen de métodos científicos simples a los más complejos, para Estime esta condición corporal. Además, este parámetro biológico está influenciado por las condiciones y características ambientales, debido a la disponibilidad de alimentos y las relaciones ecológicas en el medio. Esta información puede apoyar una adecuada gestión pesquera, ya que existe una integración de la biología pesquera y las características del entorno en el que viven. Así, la metodología aplicada en este estudio resultó exitosa en su propuesta de aplicación.

Palabras clave: Ictiofauna tropical; Conservación y desarrollo; Factor de condición; Represa en la amazonia; Biología pesquera.

\section{Introduction}

The constant interference of human activities in continental water systems, results in direct and indirect impacts on water quality, aquatic biota and the functioning of lakes, rivers, dams, between others. The including dams for mining (Carneiro et al., 2019; Barcelos et al., 2020; Reis et al., 2020; Caitano et al., 2021), agriculture, leisure, fish farming, and the construction of dams for hydroelectric plants. Its produces changes both qualitative and quantitative in productivity, as well as structural and functional changes in the environmental system (Thornton et al., 1981; Petts, 1984; Straskraba and Tundisi, 2000). The construction of a dam deeply transforms the natural characteristics of a river by reducing the flow speed, changing the water quality and the substrate, among other changes. These changes affect all organisms that live in the water, including fish, and it raises greater concern for their importance in both commercial and sport fishing (Petesse and Petrere Jr, 2012; Druzian et al., 2021). In this scenario, the Tucuruí Hydroelectric Power Plant (HPP) has grown in importance because it was the first large dam built in the Amazon, in the 1980s, and presented technical and economic results (electricity production) sufficiently significant to justify a comprehensive analysis of the ratio between the benefits produced and the high environmental costs associated with the project (Eletronorte, 2007).

The Condition Factor $(\mathrm{K}=\mathrm{W} / \mathrm{L})$ is linked to the relationship between the weight of the individual and body length, initially described for an "isometric growth" ratio, which derived from an expansion of the cubic law for living beings defined by Dr. Hebert Spencer in 1871 (Keys, 1928; Le Cren 1951; Bolger and Connolly 1989, Pope et al., 2010; Camara et al., 2011, Giarrizzo et al., 2011, Giarrizzo et al., 2015). This index is very important in animal ecology studies, even though they depend on scientific methods, from the simplest to the complex ones, to estimate this body condition, considering that they differ in individuals (Green 2001, Stevenson and Woods, 2006). There are many definitions for body condition , which include a measure of an animal's energy (or nutritional) status, especially the relative size of energy reserves, such as fat and protein, as 
this indicator represents morphological, biochemical or physiological measures of health or individual quality of life of the organisms (Peig and Green, 2009). Thus, the higher the values of (K), the better the condition of "animal health".

This indicator can also present the health of fish species and reflect the nutritional conditions and expenditure of energy reserves (Le Cren, 1951; Jobling, 2002; Gomiero and Braga, 2003). In general, it can indicate this dietary situation, since it is influenced by biotic (Leonardos and Trilles, 2003, Kortet and Taskinen, 2004, Grorud-Colvert and Sponaugle, 2006, Garcia-Ayala et al., 2014, Andrade et al., 2015, Brambilla et al., 2015) and abiotics factors (Spranza and Stanley 2000, Bojsen, 2005, Duponchelle et al., 2007).

A primary objective of community ecology is to understand the mechanisms and processes responsible for differences and similarities between communities. One approach is to compare communities that occur along environmental gradients, for example dams, which are influenced such as by stress or (un)availability of resources, thus providing valuable baseline data for research and encouraging the development of testable hypotheses, which, in turn, will lead to more definitive decisions in the studies (Angermeier and Karr, 1983). Thus, this study aims to present, using a new methodology for georeferenced maps, data on the condition factor of the four fish species that occur in the area of influence of the Tucuruí reservoir, Brazil.

\section{Methodology}

\subsection{Study Area}

The study area comprised the region of influence of the Tucuruí dam, and for the present work, there were subdivisions by regions and cities, within the boundaries of the municipalities (Figure 1 and Table 1):

- Upstream - comprises the first region above the reservoir, with lentic characteristics, including Tucuruí (Caraipé), Breu Branco, Goianésia of Pará, Novo Repartimento, Jacundá, Nova Ipixuna, Itupiranga, and Marabá.

- Downstream - comprises the region below the reservoir, characterized by a lotic environment. It includes the municipalities of Tucuruí (Icangui), Baião, Mocajuba, Cametá, and Limoeiro of Ajuru. 
Figure 1: Location of the Tucuruí (HPP) reservoir, in State of Pará, Brazil. In the map has four sanpling points in downstream region and seven sanpling points in upstream region.
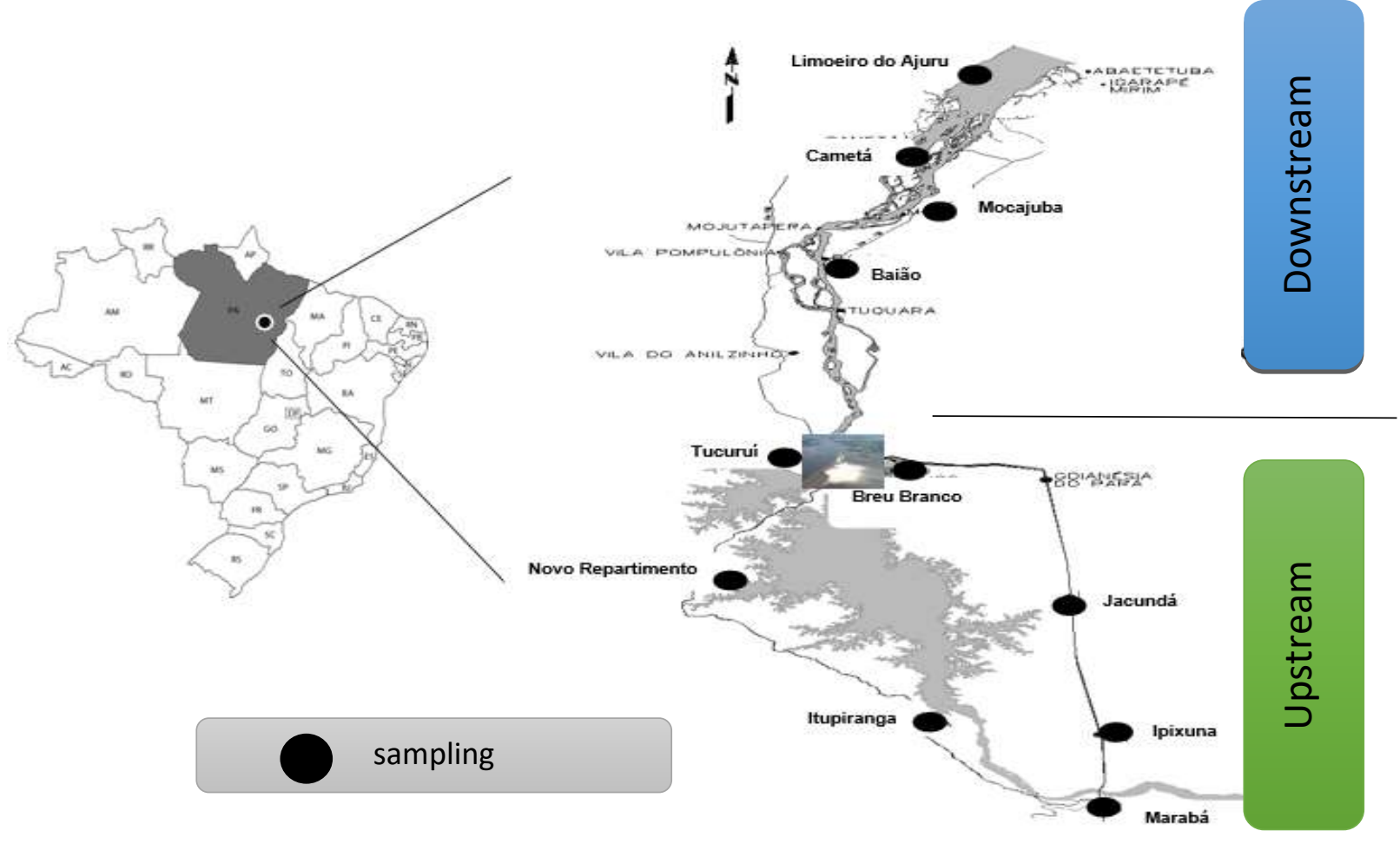

Source: Authors. 
Table 1: Description of the environments in the area of influence of the Tucuruí (HPP) and respective cartographic coordinates, in State of Pará, Brazil.

\begin{tabular}{|c|c|c|c|c|}
\hline REGION & MUNICIPALITY & \multicolumn{2}{|c|}{$\begin{array}{l}\text { (UTM) } \\
\text { (UTION }\end{array}$} & DESCRIPTION \\
\hline \multirow{7}{*}{ 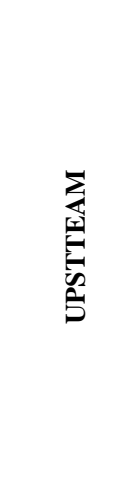 } & Marabá and Itupiranga & 692495 & 9420465 & - Region of beaches, channels and islands \\
\hline & Nova Ipixuna & 684157 & 9449367 & - Region of beaches, channels and islands \\
\hline & Jacundá & 678646 & 9489357 & - Running water in channels / - Stones and islands \\
\hline & Goianésia of Pará & 673670 & 9524623 & - Island area \\
\hline & Novo Repartimento & 644944 & 9533240 & - Island areas, considered as a reserve for base 04 \\
\hline & Breu Branco & 659986 & 9579363 & $\begin{array}{l}\text { - Area considered former Parakanã indigenous village } \\
\text { - Islands and bayou streams }\end{array}$ \\
\hline & Tucuruí (Caraipé) & 624713 & 9557202 & $\begin{array}{l}\text { - Near the dam embankment } \\
\text { - Very populated area, with islands and several bayou streams }\end{array}$ \\
\hline \multirow{7}{*}{$\begin{array}{l}\sum \\
0 \\
0 \\
0 \\
0 \\
0\end{array}$} & Tucuruí (İcangui) & 654239 & 9614818 & $\begin{array}{l}\text { - Running water in narrow channels } \\
\text { - Region of beaches and channels }\end{array}$ \\
\hline & & & & - Region of beaches, channels and islands \\
\hline & Baiao & 032000 & 9658000 & - Marginal lagoons \\
\hline & & & & -Channels in the Bacuri archipelago. \\
\hline & Mocajuba & 662197 & 9712748 & - Muddy soil (very small sediments) \\
\hline & Cametá & 672244 & 9737185 & - Area with islands, beaches and tides \\
\hline & Limoeiro OF Ajuru & 682149 & 9788946 & - Area with islands, beaches and tides, at the end of the Tocantins River \\
\hline
\end{tabular}

Source: Authors.

\subsection{Fish Capture, Screening, and Biometry}

The data of this study, previously authorized by ELETRONORTE/ELETROBRÁS, comes from experimental fisheries conducted by the team of technicians of the Fishing and Ichthyofauna Program of the company from 2000 to 2010 . It should also noted that the information on these activities was important for the conditions of the Operation License of the Tucuruí HPP requested by the State environmental agency. The major fishing gear used were gill nets, which were randomly arranged in groups of $80.00 \mathrm{~m}$, with mesh nets number $4,6,8,10,12,14$. These fisheries conducted during day and night times, with an average 24-hour length, and inspected every 3 hours.

The fish that captured, dead or alive, distributed in plastic bags and duly labeled with information on the capture site, date, and fishing net size. Subsequently, they packed in isothermal boxes with ice in the ratio of 1:1 and transported to analyze in the laboratory of the program, the Environmental Protection Center of the Tucuruí (HPP). In the laboratory, these specimens were identified based on the identification guide by Santos et al., (1984) and Santos et al., (2004), in addition to being submitted to biometric analyzes, registering with an ichthiometer graduated in millimeters, total length (Lt) and standard length (S1). The total weight (Wt) measured in grams, using an analytical balance, with an accuracy of $0.000 \mathrm{~g}$. 


\subsection{Relative Condition Factor (Kcf)}

The standard length $(\mathrm{Sl})$ - weight $(\mathrm{Wt})$ - length-weight relationships (LWR), by grouped region and sex, was estimated using the equation $\mathrm{Wt}=\mathrm{a} \cdot \mathrm{Sl}^{\mathrm{b}}$ (PAULY, 1984), where (Wt) is the total weight, ct is the standard length, (a) is the constant and (b) is the allometry coefficient (Froese, 2006). The Relative Condition Factor (Kcf), estimated by the allometric method for each region and sex separately, by comparing the estimated values according to the expression: $\mathrm{K}_{\mathrm{cf}}=\mathrm{Wt}_{\mathrm{S}} \mathrm{SL}^{\mathrm{b}}$ (Le Cren, 1951) from the total weight ratio (Wt) - standard length (Froese, 2006). After this analysis, maps will elaborate up using the Surfer $9^{\circledR}$ software (Golden Software Inc, 2010) to present this distribution of this parameter by sex, comparing among regions and showing the influences of these environments on the species.

The new methodology for applying georeferencing based on Landim et al., (2002), who mention the Surfer $9^{\circledR}$ software, which used in the elaboration of maps, but had never used with biological data.

The program has several methods, and the default is Krigim, but the result is not very faithful to the original data. Another option is the Inverse Distance to a Power, which presents good results, but is still not very faithful to the original data. The Minimum Curvature is a smoothing method (spline) and provides a reasonable result for a quick evaluation of the spatial behavior of the variable. Thus, the following procedure was appropriate in the preparation of the maps: separation of the data in Excel® spreadsheets (Windows, 2010), creation of the BLN file (Golden Software Blankink), selecting the data grid method and choosing the Minimun Curvature, and finally making the choice of New 3D Surface, as we sought fidelity to the data and better smoothing of the curves.

For the preparation of maps, species separated by sex and the downstream and upstream regions. This is due to the method chosen, thus, the results would be more suitable for the representations, which even required a minimum number of data.

\section{Results and Discussion}

\subsection{Length-Weight Relationships (LWR)}

During the period, 1,826 individuals of the Botinho species (H. Wilderi) were collected in the downstream region, and 248 individuals in the upstream region; for Mandubé (A. ucayalensis), 1,289 individuals were collected in the downstream region and 2,781 individuals in the upstream region; as for Sardinha Papuda (T.trifurcatus), 417 individuals were collected in the downstream region and 1,591 individuals in the upstream region; and for Uéua Cachorrinho (A. falcirostris), 276 individuals were collected in the downstream region and 1,758 individuals in the upstream region. The standard length (S1) weight total $(\mathrm{Wt})$ or length-weight relationships (LWR), distributions were analyzed for the four species by region and by grouped and separated sex for Botinho (H. wilderi), Mandubé (A. ucayalensis), Sardinha Papuda (T.trifurcatus), and Uéua Cachorrinho (A. falcirostris) (Figure 2)

For Botinho (H. Wilderi), the minimum standard length and the minimum total weight were higher in the upstream region, $90.00 \mathrm{~mm}$ and $19.00 \mathrm{~g}$, respectively. As for this region, the averages were higher, $135.40 \pm 29.00 \mathrm{~mm}$ and $56.50 \pm$ $36.91 \mathrm{~g}$. In relation to the length for this species, in the downstream region, the highest frequency was for the $130.00 \mathrm{~mm}$ length class. In addition, for the upstream region, the highest frequencies were in the 75.00 to $90.00 \mathrm{~mm}$ classes.

For Mandubé (A. ucayalensis), the minimum standard length and the minimum total weight were higher in the downstream region, $80.00 \mathrm{~mm}$ and $11.20 \mathrm{~g}$, respectively. The highest averages of $(\mathrm{Sl})$ and $(\mathrm{Wt})$ were for the upstream region, $178.30 \pm 32.36 \mathrm{~mm}$ and $69.70 \pm 44.33 \mathrm{~g}$. In relation to the length for this species, the region with the highest frequency was in the $175.00 \mathrm{~mm}$ length class. In addition, for the upstream region, the highest frequency was in the $230.00 \mathrm{~mm}$ length class.

For Sardinha Papuda (T. trifurcatus), the minimum standard length and minimum total weight were greater in the downstream region, $100.00 \mathrm{~mm}$ and $17.60 \mathrm{~g}$, respectively. The highest averages of $(\mathrm{Sl})$ and $(\mathrm{Wt})$ were for the upstream region, 
$157.30 \pm 38.36 \mathrm{~mm}$ and $66.30 \pm 40.73 \mathrm{~g}$. Males prevailed in the smaller size classes, and females, in the intermediate classes. In relation to the length for this species, for the downstream region, the highest frequencies were between the 120.00 to $140.00 \mathrm{~mm}$ length classes. For the upstream region, the highest frequencies were in the 175.00 to $185.00 \mathrm{~mm}$ classes.

For Uéua Cachorrinho, the minimum standard length was higher in the downstream region and the minimum total weight was higher in the upstream region. The highest averages of $(\mathrm{Sl})$ and $(\mathrm{Wt})$ were for the upstream region, $232.00 \pm$ $43.61 \mathrm{~mm}$ and $141.40 \pm 81.91 \mathrm{~g}$. In relation to the length for this species, for the downstream region, the highest frequencies were between the 190.00 to $205.00 \mathrm{~mm}$ length classes. Moreover, for the upstream region, the highest frequencies were in the 220.00 and $235.00 \mathrm{~mm}$ classes.

The length-weight relationship (LWR) can describe growth, which related to the life cycle of a species, being a good indicator of feeding and reproductive activities (Weatherley, 1972). However, changes in environmental conditions, such as dams or the formation of reservoirs, can influence the type of growth (Araya et al., 2005). 
Figure 2: The length-weight relationships (LWR), for grouped sexes and by region (downstream and upstream), to: (a) Botinho (H. wilderi), (b) Mandubé (A. ucayalensis), (c) Sardinha Papuda (T.trifurcatus), and (d) Uéua Cachorrinho (A. falcirostris).

(a)
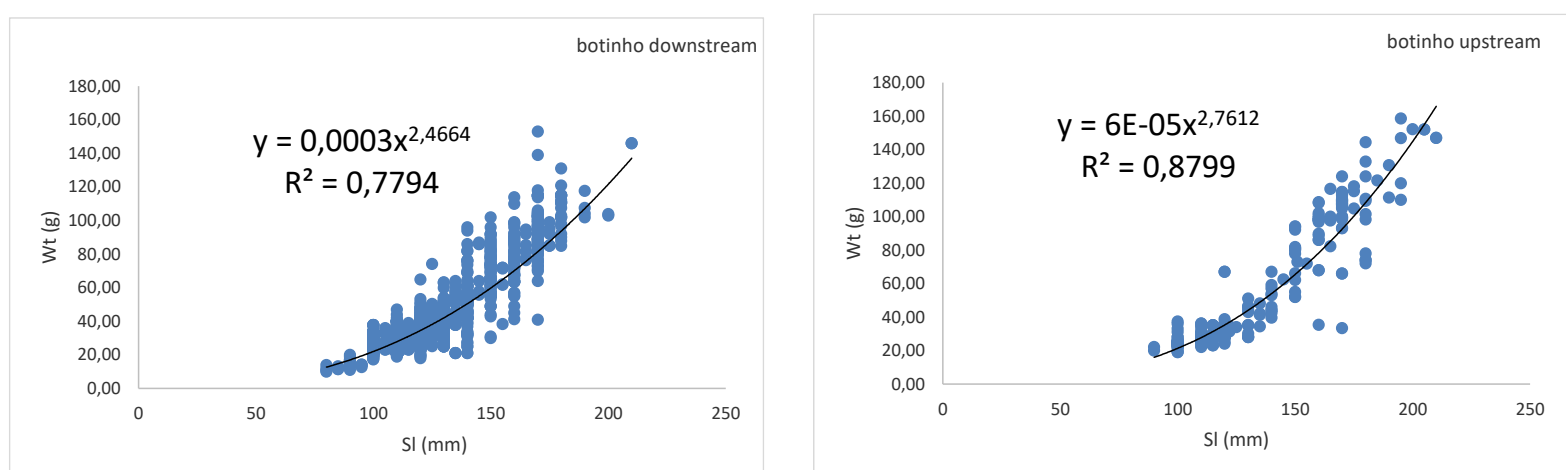

(b)
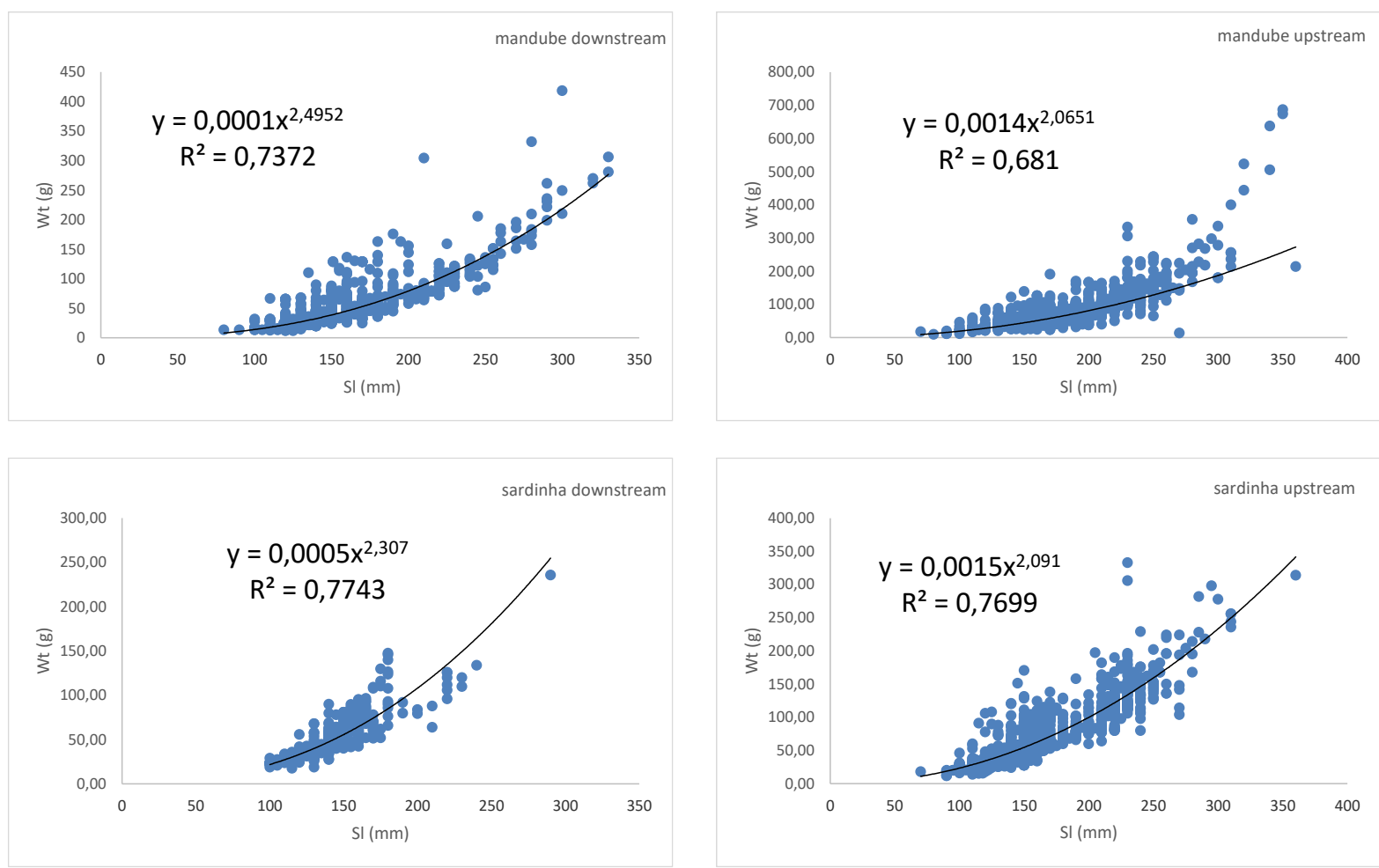

(c)

(d)
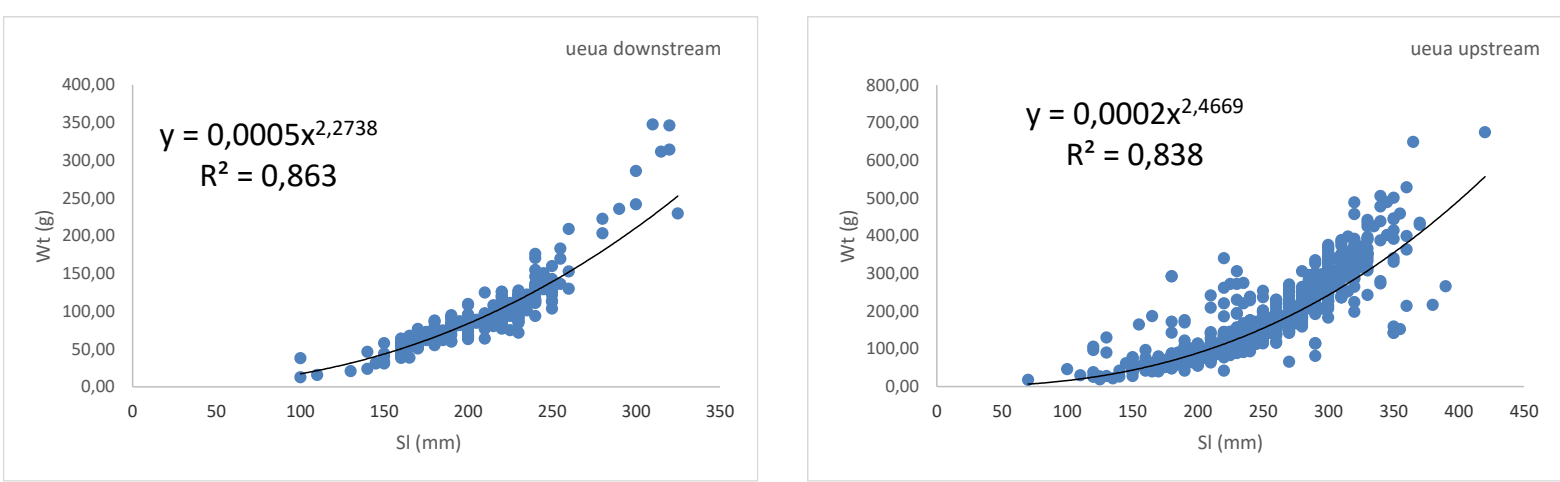

Source: Authors.

\subsection{Condition Factor}

In relation to the $(\mathrm{Kcf})$, for Botinho (H. wilderi), the predominant occurrence was of females, from 2000 to 2010 , in the downstream region, with values from 1.07 (individual of $140.00 \mathrm{~mm}$ and $21.04 \mathrm{~g}$ ) to 4.89 (individual of $195.00 \mathrm{~mm}$ and 
$96.05 \mathrm{~g}$ ), but with lower values in relation to males, which was between 1.27 (individual of $160.00 \mathrm{~mm}$ and $25.03 \mathrm{~g}$ ) to 4.99 (individual of $125.00 \mathrm{~mm}$ and $74.15 \mathrm{~g}$ ). Regarding the upstream region, the frequency was the same in this period, with the values of (Kcf) for females from 0.23 (individual of $170,00 \mathrm{~mm}$ and $33.40 \mathrm{~g}$ ) to 0.41 (individual with $120.00 \mathrm{~mm}$ and $67.00 \mathrm{~g}$ ). For males, it was from 4.09 (individual of $130.00 \mathrm{~mm}$ and $28.09 \mathrm{~g}$ ) to 1.12 (individual of $135.00 \mathrm{~mm}$ and $37.28 \mathrm{~g}$ ).

For Mandubé (A. ucayalensis), there was a high frequency predominance of females for the highest values of (Kcf), in the downstream region, with the values from 0.71 (individual of $125.00 \mathrm{~mm}$ and $12.06 \mathrm{~g}$ ) to 5.33 (individual of $135.00 \mathrm{~mm}$ and $110.08 \mathrm{~g}$ ). For males, in this region, the (Kcf) values were from 0.68 (individual of $170.00 \mathrm{~mm}$ and $25.04 \mathrm{~g}$ ) to 5.38 (individual of $110.00 \mathrm{~mm}$ and $68.80 \mathrm{~g}$ ). For the upstream region, over the years, (Kcf) was higher for males, with values from 5.90 (individual of $170.00 \mathrm{~mm}$ and $24.00 \mathrm{~g}$ ) to 46,92 (individual of $170.00 \mathrm{~mm}$ and $190.90 \mathrm{~g}$ ). For females, the values ranged from 5.90 (individual of $170.00 \mathrm{~mm}$ and $26.20 \mathrm{~g}$ ) to 44.82 (individual of $140.00 \mathrm{~mm}$ and $122.08 \mathrm{~g}$ ). For this species, the upstream region had the highest values of (Kcf), thus being more conducive to the survival of this species.

In what concerns Sardinha Papuda (T. trifurcatus), there was a predominance of higher (Kcf) values for females in the downstream region, with values from 2.53 (individual of $130.00 \mathrm{~mm}$ and $19.09 \mathrm{~g}$ ) to 9.25 (individual of $180.00 \mathrm{~mm}$ and $140.56 \mathrm{~g}$ ). For males, in this region, the values ranged from 3.10 (individual of $115.00 \mathrm{~mm}$ and $17.61 \mathrm{~g}$ ) to 10.07 (individual of $140.00 \mathrm{~mm}$ and $90.00 \mathrm{~g}$ ). For the upstream region, the frequency of (Kcf) values, in the study period, were for females, ranging from 7.21 (individual of $118.00 \mathrm{~mm}$ and $15.50 \mathrm{~g}$ ) to 48.09 (individual of $150.00 \mathrm{~mm}$ and $170.70 \mathrm{~g}$ ). For males, in this region, the values ranged from 7.54 (individual of $110.00 \mathrm{~mm}$ and $14.00 \mathrm{~g}$ ) to 45.74 (individual of $145.00 \mathrm{~mm}$ and $151.26 \mathrm{~g}$ ). This region was apparently more suitable for the survival of this species.

For Uéua Cachorrinho (A. falcirostris), there was a predominance of ( $\mathrm{Kcf})$ values in the downstream region, for females, ranged from 3.07 (individual of $230.00 \mathrm{~mm}$ and $71.89 \mathrm{~g}$ ) to 10.77 (individual of $100.00 \mathrm{~mm}$ and $38.00 \mathrm{~g}$ ). For males, the values were from 3.17 (individual of $140.00 \mathrm{~mm}$ and $24.05 \mathrm{~g}$ ) to 6.62 (individual of $240.00 \mathrm{~mm}$ and $171.04 \mathrm{~g}$ ). For the upstream region, there was also the majority of $(\mathrm{Kcf})$ values with predominance of females, with values between 0.70 (individual of $220.00 \mathrm{~mm}$ and $42.00 \mathrm{~g}$ ) at 7.93 (individual of $130.00 \mathrm{~mm}$ and $130.06 \mathrm{~g}$ ). For males, the values were between 1.23 (individual of $135.00 \mathrm{~mm}$ and $22.09 \mathrm{~g}$ ) to 5.05 (individual of $70.00 \mathrm{~mm}$ and $18.00 \mathrm{~g}$ ). For this species, the downstream region was more favorable for development.

Froese (2006) refers to some assumptions for the application of (Kcf) with a minimum sample number, in addition to close numbers of individuals in the length classes. Thus, it is not necessary to measure a large number of individuals in each class since there are statistical implications involved in the use of very heterogeneous samples (Camara et al., 2011). These findings are opposed due to uncertainties in experimental fisheries, and it is also not common to scientifically dispense with the availability of a database and be treated continuously until the expected result is obtained. Thus, the present work aimed to generate as much information about the species as possible with the available data from the fisheries sampling. The condition factor, if individually exposed, is established as an indicator of the energy reserves of the tissues, with the expectation that an individual or fish in relatively better condition has higher growth rates and higher reproductive and survival potential in relation to another in an unsatisfactory condition - also considering similar and comparable environments (Pope and Kruse, 2007; Camara et al., 2011).

For the Condition Factor Maps developed, from 2000 to 2010, according to separate sexes and by region. Likewise, it is possible to have a spatial and temporal notion in the distribution of this parameter for Botinho (H. wilderi) (Figure 3), Mandubé (A. ucayalensis) (Figure 4), Sardinha Papuda (T. trifurcatus) (Figure 5), and Uéua Cachorrinho (A. falcirostris) (Figure 6). Thus, it is possible to compare these maps with Table 1, which describes the environment and discusses the most favorable environmental conditions for occurrence. 
Figure 3: Condition factor for Botinho (H. Wilderi) by region and separate sexes: (a) Botinho females downstream, (b) Botinho males downstream, (c) Botinho females upstream, and (d) Botinho males upstream. Its possible to compare these maps with Table 1, which describes the environment and discusses the most favorable environmental conditions for occurrence.

(a) Botinho females downstream

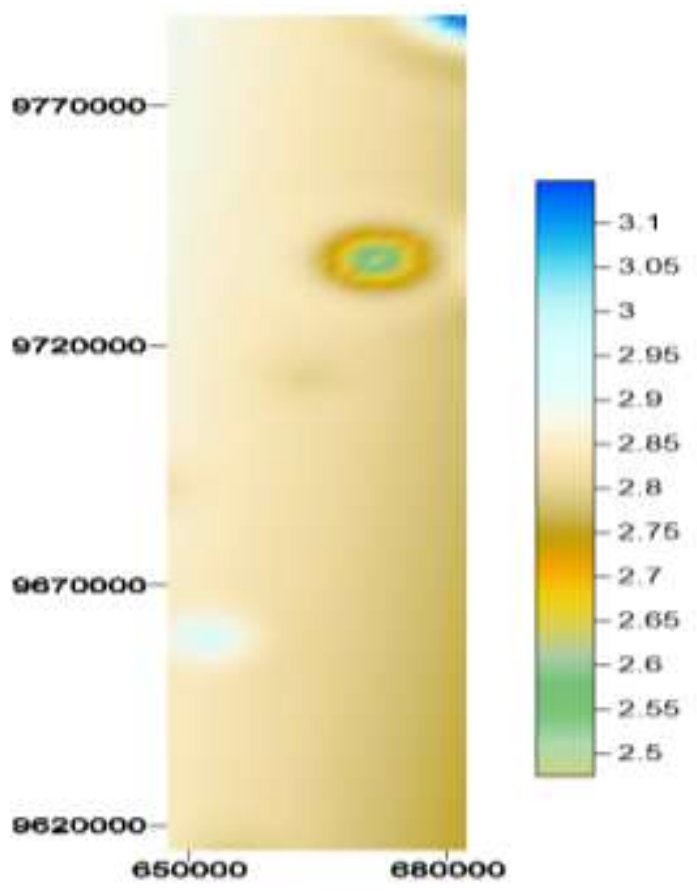

(c) Botinho females uptream

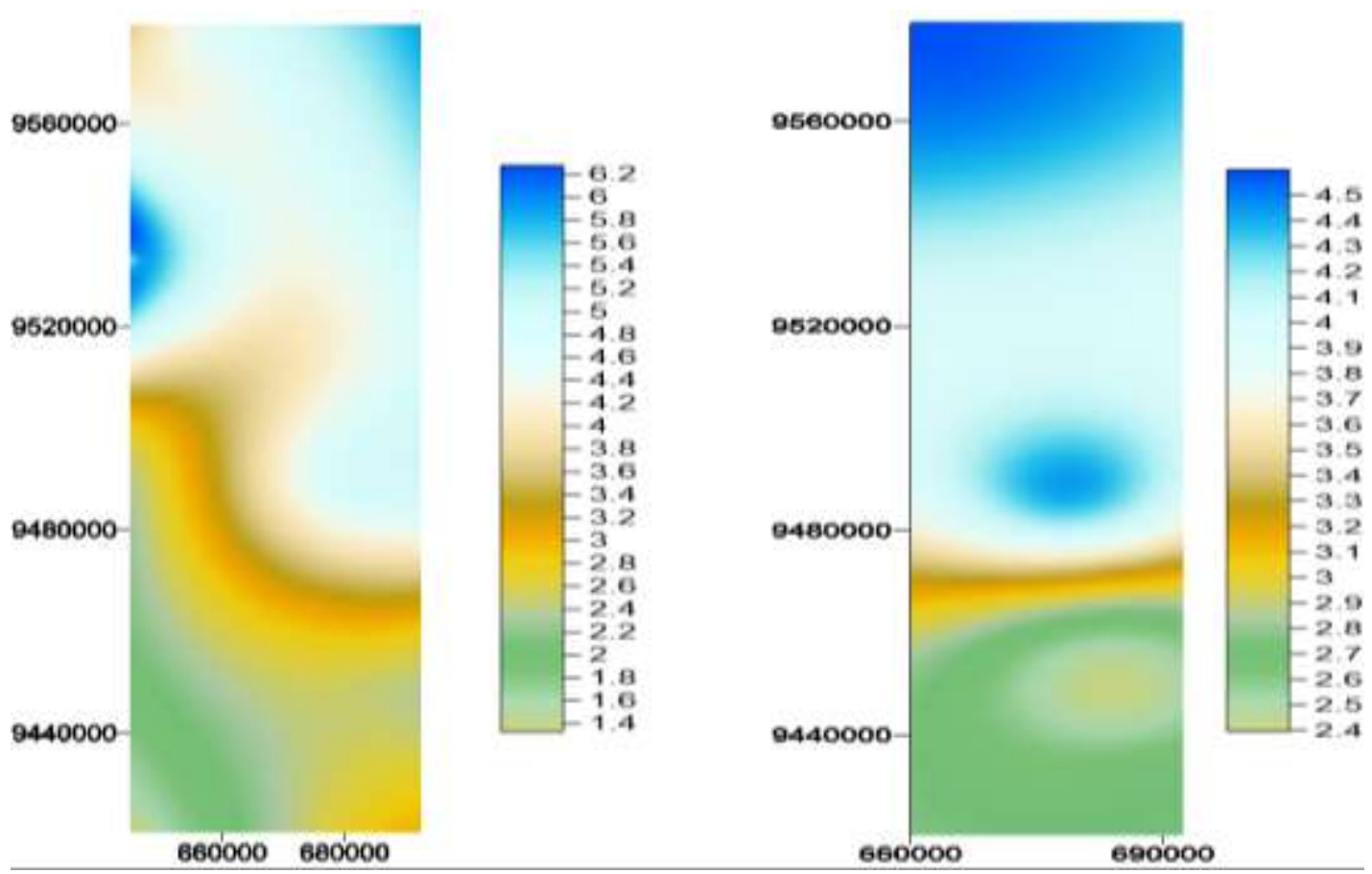

(b) Botinho males downstream

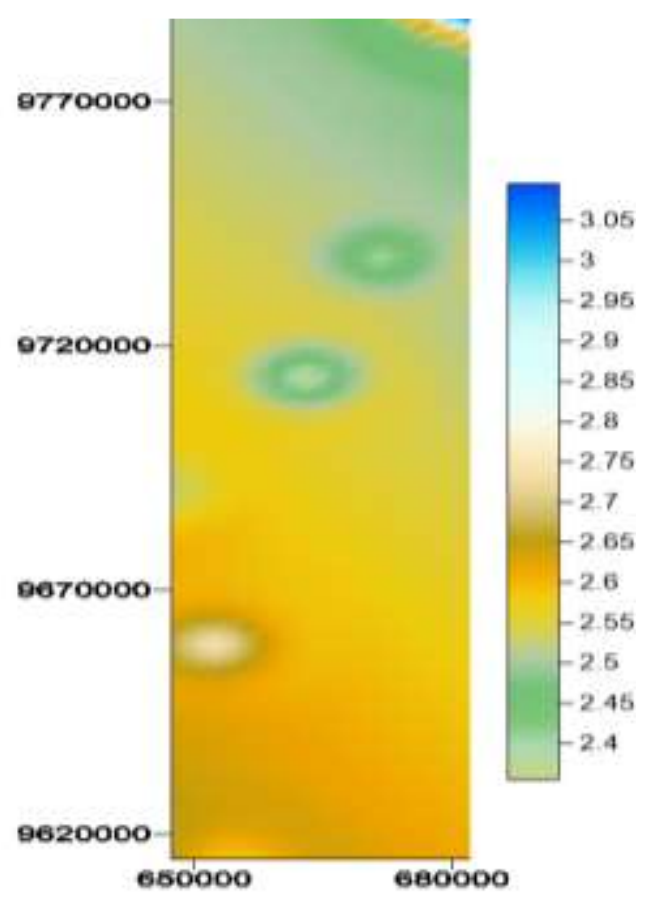

(d) Botinho ales uptream

Source: Authors. 
Figure 4: Condition factor for Mandubé (A. ucayalensis), by region and separate sexes: (a) Mandubé females downstream, (b) Mandubé males downstream, (c) Mandubé females upstream, and (d) Mandubé males upstream. Its possible to compare these maps with Table 1, which describes the environment and discusses the most favorable environmental conditions for occurrence.

(a) Mandubé females downstream

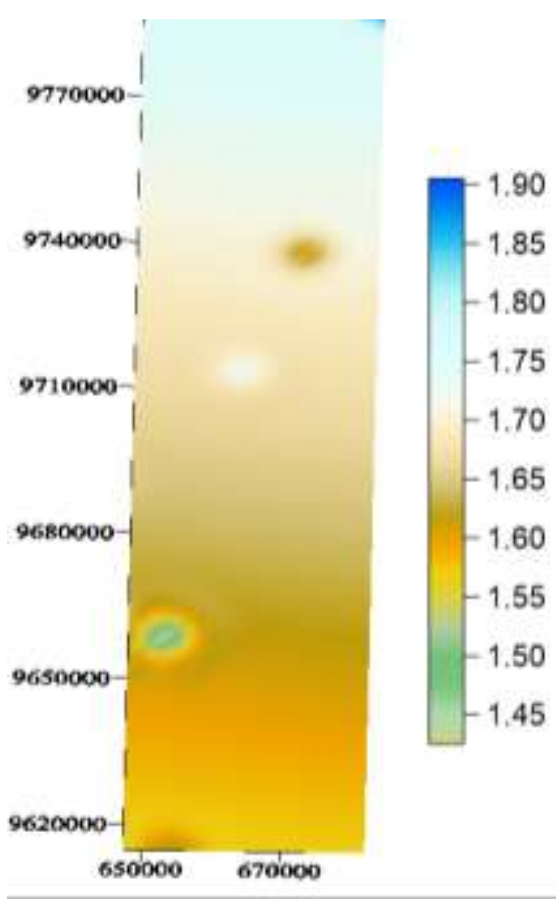

(c) Mandubé females upstream

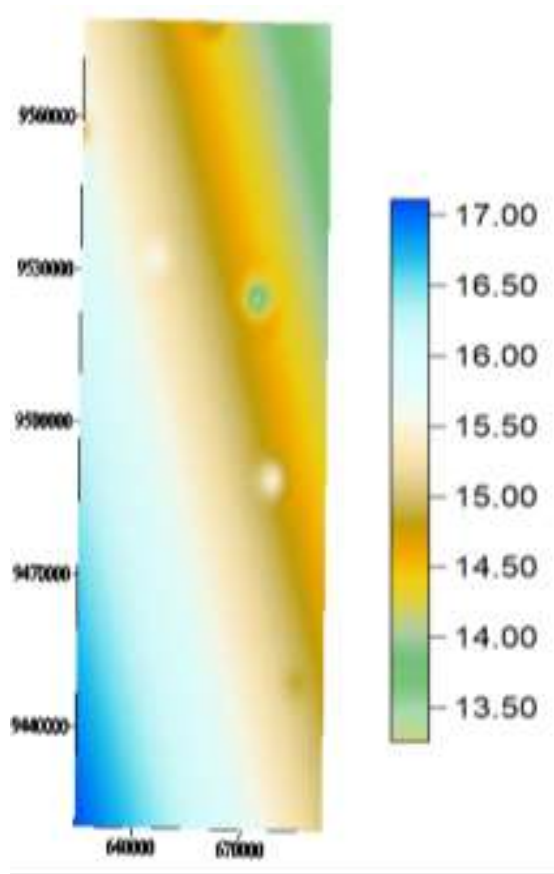

(b) Mandubé males downstream

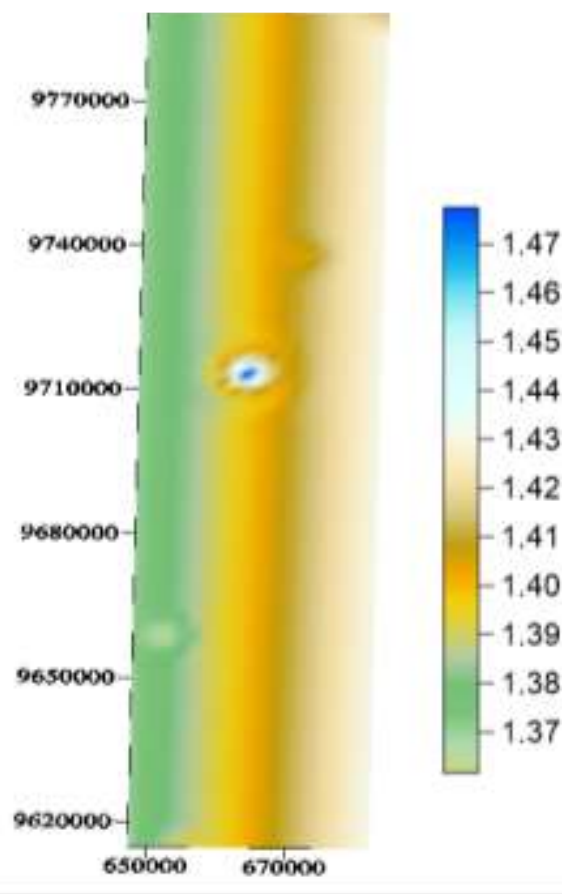

(d) Mandubé males upstream

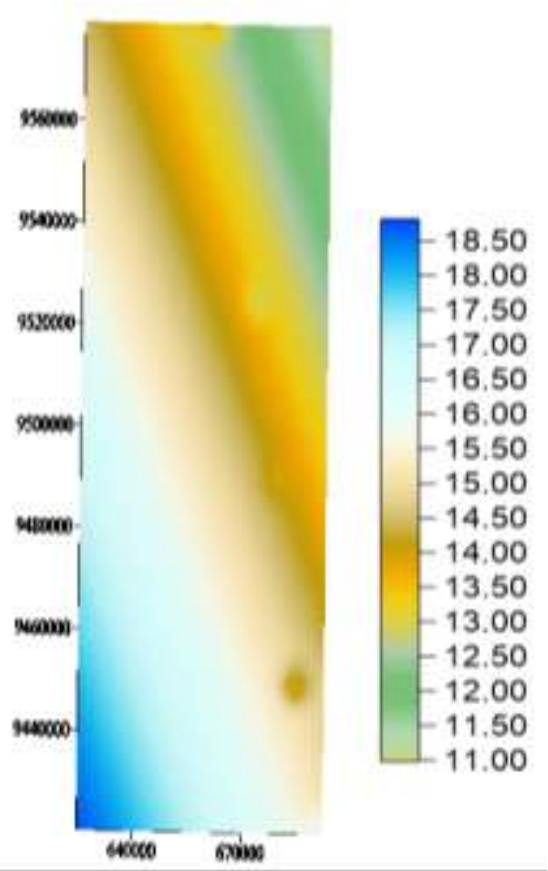


Figure 5: Condition factor for Sardinha Papuda (T. trifurcatus), by region and separate sexes: (a) Sardinha females downstream, (b) Sardinha males downstream, (c) Sardinha females upstream, and (d) Sardinha males upstream. Its possible to compare these maps with Table 1, which describes the environment and discusses the most favorable environmental conditions for occurrence.

(a) Sardinha females downstream

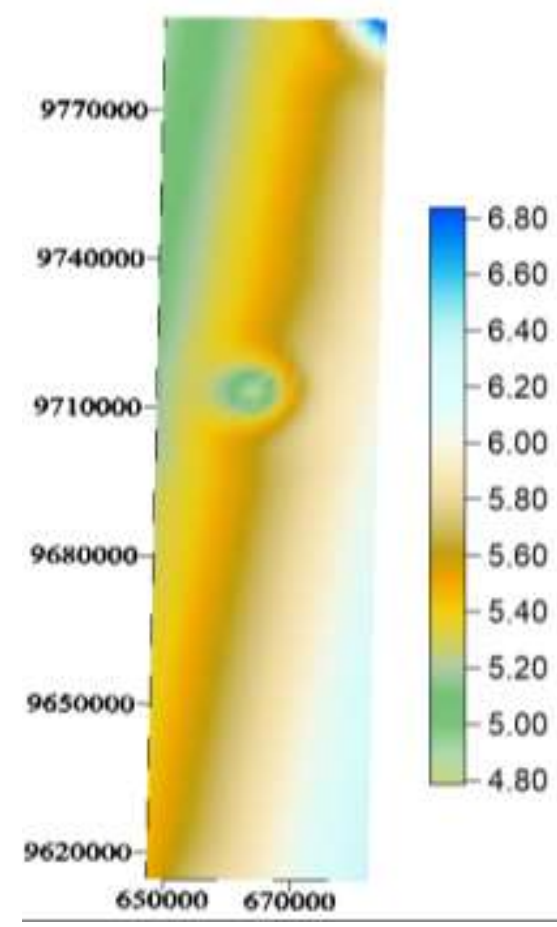

(c) Sardinha females upstream

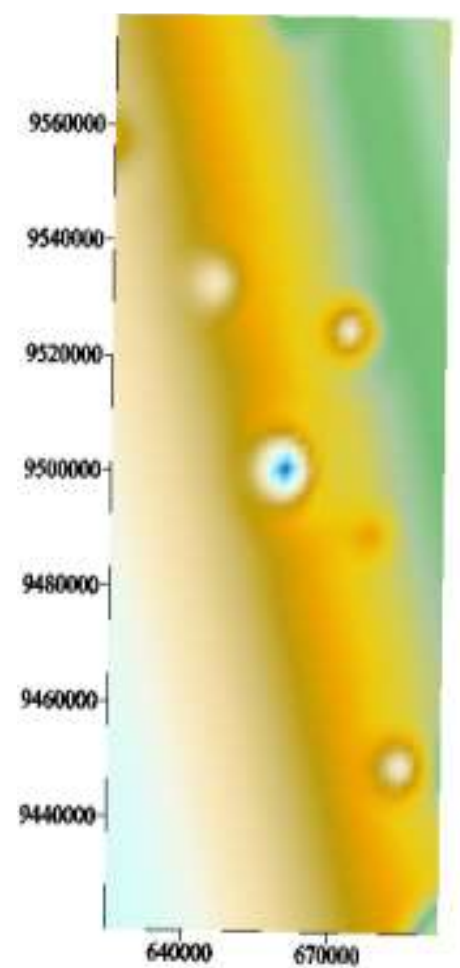

(b) Sardinha males downstream

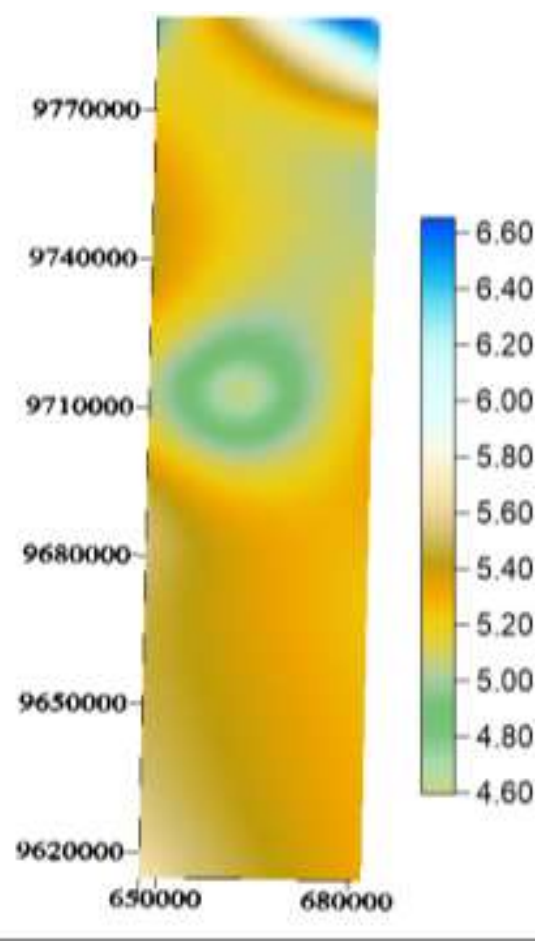

(d) Sardinha males upstream

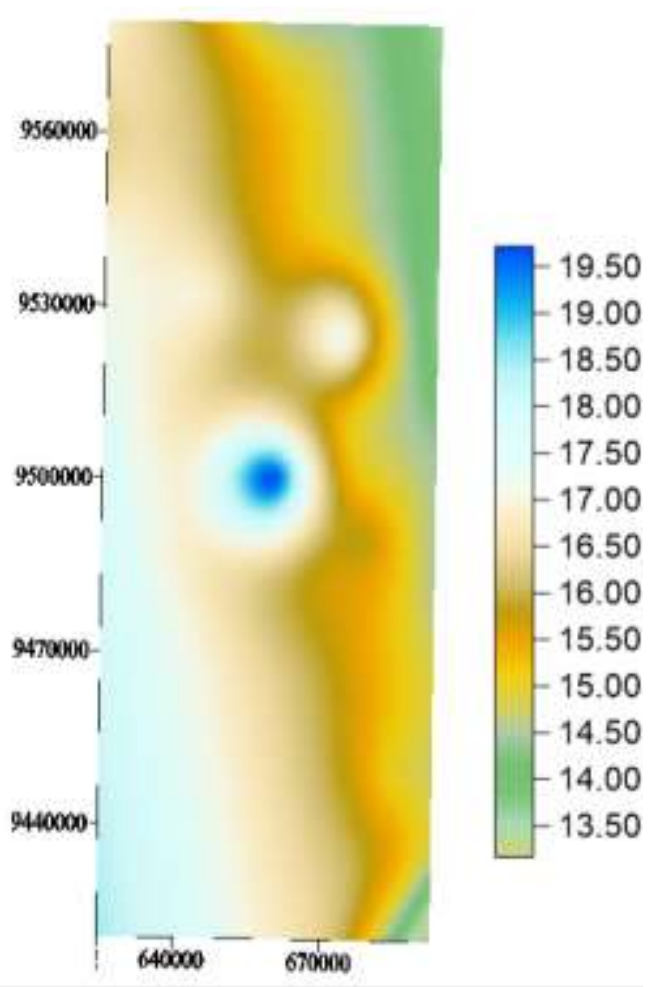

Source: Authors. 
Figure 6: Condition factor for Uêua Cachorrinho (A. falcirostris), by region and separate sexes: (a) Uéua females downstream, (b) Uéua males downstream, (c) Uéua females upstream, and (d) Uéua males upstream. Its possible to compare these maps with Table 1, which describes the environment and discusses the most favorable environmental conditions for occurrence.

(a) Uéua females downstream

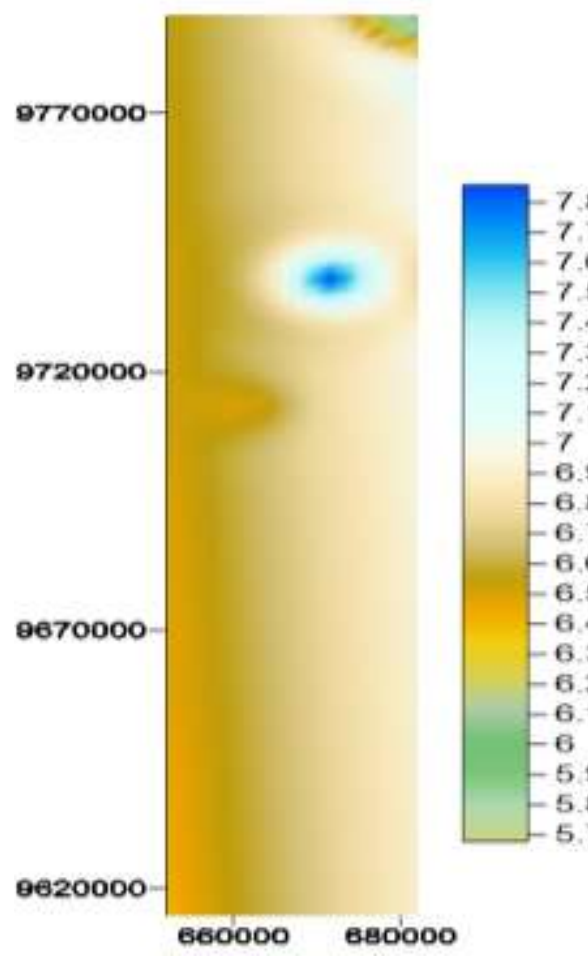

(c) Uéua females upstream

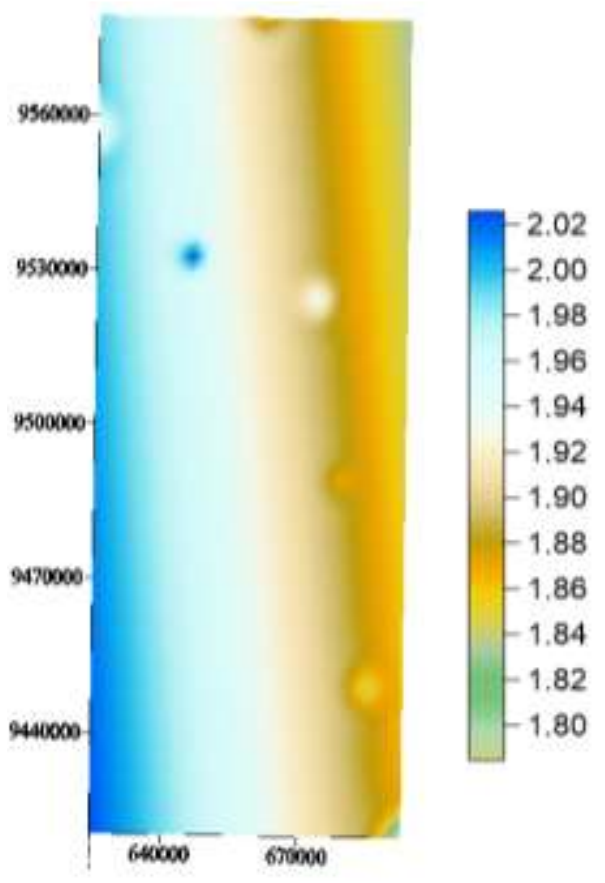

(b) Uéua males downstream

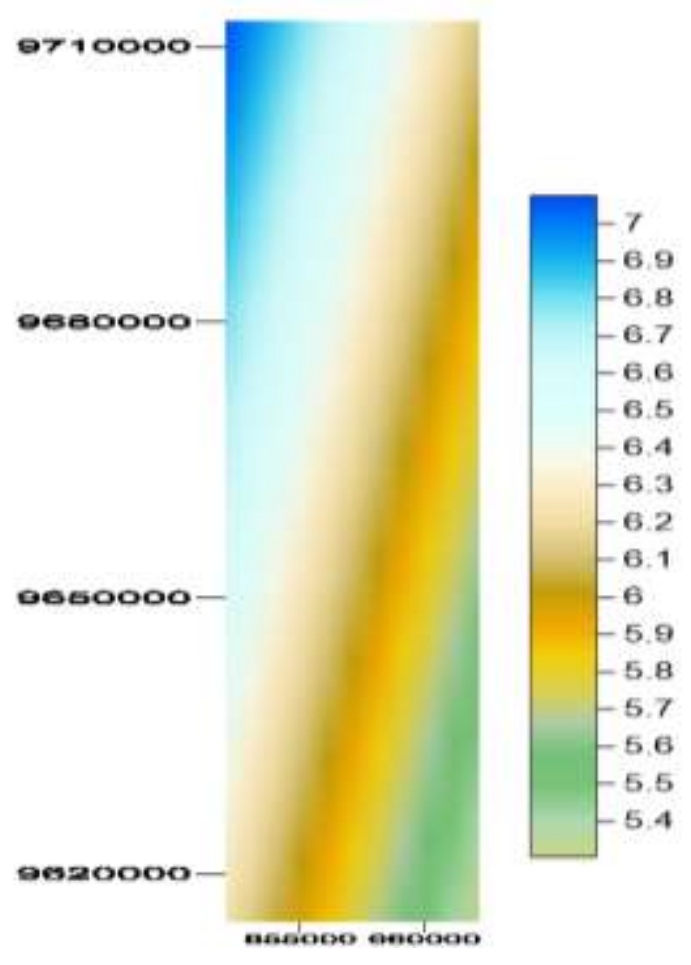

(d) Uéua males upstream

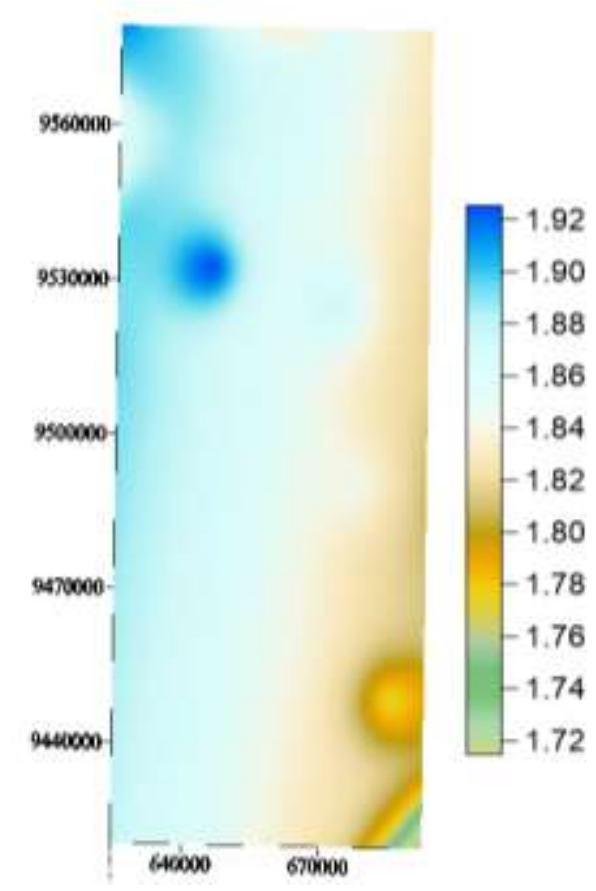

Source: Authors. 
The individual sizes of the organisms and their taxonomy used to inform about the management and conservation of some water ecosystems (Petchey and Belgrano, 2010; Gomes, 2015). Gubiani et al., (2020), in a bibliographic review work, mention that the (Kcf) method estimated by Dr. Le Cren (1951) is widely used to estimate the body condition of fish, however, there are criticisms in its application by many authors. In spite of this, in the work of estimating the (Kcf) for four species that occur in the area of influence of the Tucuruí (HPP), it concluded that the ratio was widely applied in verifying the impacts of the construction of the dam on the species studied.

The research results presented and achieved the objectives of analyzing biological information, without previously estimated data, of four species of fish.

\section{Final Considerations}

The species were not effectively harmed by the construction of the Tucuruí (HPP), even if some information is discrepant, the dam is not directly affecting the overexploitation of the species, in relation to the study of fishery resources. It demonstrated that there is a region more favorable to the survival, of the organisms or species, than another region. For females and males of Uéua Cachorrinho (A. falcirostris), the downstream region is more prone to survival than the upstream region. For Botinho (H. wilderi), Mandubé (A. ucayalensis), and Sardinha Papuda (T. trifurcatus), there the highest values of the condition factor, occurred for females and males, in the downstream region.

A future proposal for similar works would be to analyze more recent data and compare with the information generated by this work. Another suggestion would be the analysis with other species or between groups of similar fishes. The expansion of the methodology could also be applied to other groups of aquatic fauna. But emphasizing that the division of regions must be carried out for comparisons.

Como Therefore, the use of the proposed methodology proved to be applicable and useful in providing reliable and easy to interpret information and presentation of ecological relationships.

\section{Acknowledgments}

The authors wish to thank ELETRONORTE/ ELETROBRÁS for the data. To PPGEAP/NEAP/UFPA. To CAPES for doctoral fellowship for Fábio Alexandre Travassos.

\section{References}

Andrade, M. C., Jesus, A. J. S., \& Giarrizzo, T. (2015). Length-weight relationships and condition factor of the eaglebeak pacu Ossubtus xinguense Jégu, 1992 (Characiformes, Serrasalmidae), an endangered species from Rio Xingu rapids, northern Brazil. J. Biol., vol. 75, no. 3 (suppl.), p. S102-S105.

Angermeier, P. L., \& Karr, J.R. (1983). Fish communities along environmental gradients in a system of tropical streams. Environmental Biology of Fishes.

Araya, P. R., Agostinho, A. A., \& Bechara, J.A. (2005). The influence of dam construction on a population of Leporinus obtusidens (Valenciennes, 1847) (Pisces, Anostomidae) in the Yacyreta Reservoir (Argentina). Fisheries Research, v. 74, p. 198-209.

Barcelos, G. J. N., Lage, J. R. D., \& Cordeiro, J. S. (2020). Caracterização das barragens de rejeitos de mineração no Brasil. Research, Society and Development, [S. l.], v. 9, n. 3, p. e135932478, 2020. DOI: 10.33448/rsd-v9i3.2478. https://rsdjournal.org/index.php/rsd/article/view/2478.

Bojsen, B. H. (2005). Diet and condition of three fish species (Characidae) of the Andean foothills in relation to deforestation. Environmental Biology of Fishes, 73: 61-73.

Bolger, T., \& Connolly, P. L. (1989). The selection of suitable indices for the measurement and analysis of fish condition. Journal of Fish Biology, 34(2), 171182 .

Brambilla, E. M., Garcia-Ayala, J. R., Travassos, F. A., Carvalho, E. D., David, G. S. (2015). Relação peso-comprimento das principais espécies de peixes comerciais do reservatório de tucurui (bacia do tocantins/araguaia, Brasil). Boletim do Instituto de Pesca, v. 41, n. 3, p. 665-670.

Caitano, T. B. dos S., Silva, E. R. P. da, \& Alves, C. N. (2021). Caracterização e análise de segurança das barragens de mineração de ferro situadas no estado do Pará, Brasil. Research, Society and Development, 10(3), e35810313384. https://doi.org/10.33448/rsd-v10i3.13384 
Camara, E. M., Caramaschi, E. P., \& Petry, A.C. (2011). Fator de condição: bases conceituais, aplicações e perspectivas de uso em pesquisas ecológicas com peixes. Ecologia Australis. 5(2): 249-274.

Carneiro, C. S., Pena, E. H. B., Cordeiro, J., Santos, C. I. F. dos, Bernardes, C. D., \& Cordeiro, J. L. (2019). Diagnóstico da degradação ambiental de um trecho do Rio do Peixe rm Itabira (MG) e proposição de medidas para a sua restauração. Research, Society and Development, [S. l.], v. 8, n. 3, p. e1483843, 2019. DOI: $10.33448 /$ rsd-v8i3.843. https://rsdjournal.org/index.php/rsd/article/view/843.

Druzian, R. A. ., Fonseca, J. R. S. ., Colombari Neto, J. ., Debona, T., Santos, V. V. dos, Silva, P. R. L. da ., Maciel, A. L., Orsi, C. H. ., Fernandes, C., Reis, A. N. dos ., Fernandes, C., \& Baumgartner, G. (2021). Pequena central hidrelétrica afeta a estrutura populacional do lambari do rabo vermelho Psalidodon aff. fasciatus (Cuvier 1819). Research, Society and Development, 10(10), e51101018582. https://doi.org/10.33448/rsd-v10i10.18582

Duponchelle, F., Lino, F., Hubert, N., Panfili, J., Renno, J. F., Baras, E., Torrico, J.P.; Dugue, R., \& Nuñez, J. (2007). Environment-related life-history trait variations of the red-bellied piranha Pygocentrus nattereri in two river basins of the Bolivian Amazon. Journal of Fish Biology, 71:1113-1134.

Eletronorte. (2007). Diagnóstico preliminar do perfil socioeconômico pescadores ribeirinhos da área de influência do reservatório de Tucuruí. Brasília.

Froese, R. (2006). Cube law, condition factor and weight-length relationships: history, meta-analysis and recommendations. Blackwell Verlag, Berlin, J. Appl. Ichthyol. 22, 241-253.

Garcia-Ayala, J. R., Brambilla, E. M., Travassos, F. A., Carvalho, E. D., \& David, G. S. (2014). Length-weight relationships of 29 fishes of the Tucuruí reservoir (Tocantins/Araguaia basin, Brazil). Journal of Applied Ichthyology, 30(5): 1092-1095.

Gomes, L.C. (2015). Efeitos dos regimes de operação de reservatórios na transferência de energia em cadeias alimentares de peixes neotropicais. [Dissertação de Mestrado]. Universidade Estadual do Oeste do Paraná, PR.

Gomiero, L. M., \& Braga, F. M. S. (2003). Relação peso-comprimento e fator de condição para Cichla cf. ocellaris e Cichla monoculus (Perciformes,Cichlidae) no reservatório Volta Grande - MG/SP. Acta Scientiarum: Biological Scienses: 25(1): 79-86.

Grorud-Colvert, K., \& Sponaugle, S. (2006). Influence of condition on behavior and survival potential of a newly settled coral reef fish the bluehead wrasse Thalassoma bifasciatum. Marine Ecology Progress Series, 327: 279-288.

Gubiani, É. A., Ruaro, R., Ribeiro, V. R., Fé, U. M. G. S. (2020). Relative condition factor: Le Cren's legacy for fisheries science. Acta Limnol. Bras., Rio Claro, v. 32, e3.

Giarrizzo, T., Sena, R. R. O. de, Andrade, M. C., \& et. al., (2015). Length-weight and length-length relationships for 135 fish species from the Xingu River (Amazon Basin, Brazil). Journal of Applied Ichthyology, 31, 1-10.

Giarrizzo, T., Bastos, D., \& Andrade, M.C. (2011). Length-weight relationships for selected fish species of Rio Trombetas biological reserve: A reference study for the Amazonian basin. Journal of Applied Ichthyology, 27, 1422-1424.

Jobling, M. (2002). Environmental Factors and Rates of Development and Growth. Handbook of Fish. Biology and Fisheries, Volume 1, 97-122.

Keys, A. B. (1928). The length-weight relation in fishes. Proceedings of the National Academy of Science of the United. States of America, 14: $922-925$.

Kortet, R., \& Taskinen, J. (2004). Parasitism, condition and number of front head breeding tubercles in roach (Rutilus rutilus). Ecology of Freshwater Fish, 13: $119-124$.

Landim, P. M. B, Monteiro, R. C, \& Corsi, A.C. (2002). Introdução à confecção de mapas pelo software SURFER. DGA,IGCE,UNESP/Rio Claro, Lab. Geomatemática, Editora Texto Didático, 08, $21 \mathrm{pp}$

Le Cren, E. D. (1951). The lenght-weight relationship and seasonal cycle in gonad weight and condition in the perch (Perca fluviatis). Journal of Animal Ecology, Oxford, v. 20, p. 201-219.

Leonardos, I., \& Trilles, J.P. (2003). Host parasite relationships: occurrence and effect of the parasitic isopod Mothocya epimerica on sand smelt Atherina boyeri in the Mesolongi and Etolikon Lagoons (W.Greece). Diseases of Aquatic Organisms, 54: 243-251.

Petchey, O. L., \& Belgrano, A. (2010). Body-size distributions and size-spectra: universal indicators of ecological status? Biol. Lett.

Petesse, M. L., \& Petrere Jr, M. (2012). Tendency towards homogenization in fish assemblages in the cascade reservoir system of the Tietê river basin, Brazil. Ecol Eng. 48:109-16.

Peig, J., \& Green, A.J. (2009). New perspectives for estimating body condition from mass/length data: the scaled mass index as an alternative method. Oikos, 2009, 118(12), 1883-1891.

Petts, G. E. (1984). Impounded Rivers, Perspectives for Ecological Management. London, John Wiley \& Sons. 1984.

Pope, K. L., Lochmann, S. E., \& Young, M.K. (2010). Methods for Assessing Fish Populations. Nebraska Cooperative Fish \& Wildlife Research Unit, Staff Publications. Paper 73.

Pope, K. L. , \& Kruse, C.G. (2007). Assessment of fish condition data. Analysis and Interpretation of Freshwater Fisheries Data. American Fisheries Society, 51-56.

Reis, D. A. dos, Roeser, H. M. P., \& Santiago, A. da F. (2020). Impacto ambiental nos sedimentos do tributário do Rio Doce após o rompimento da barragem de Fundão. Research, Society and Development, 9(2), e01921895. https://doi.org/10.33448/rsd-v9i2.1895 
Santos, G. M. dos, Mérona, B. de, Juras, A. A., \& Jegu, M. (2004). Peixes do baixo rio Tocantins: 20 anos depois da Usina Hidrelétrica de Tucuruí. Eletronorte, Brasília.

Santos, G. M. dos, Jegu, M., \& Mérona, B. (1984). Catálogo de peixes comerciais do baixo rio Tocantins: Projeto Tucuruí. Manaus, ELETRONORTE/CNPq/INPA. 85p.

Spranza, J. J., \& Stanley, E. H. (2000). Condition, growth, and reprodutive styles of fihes exposed to different environmental regimes in a prairie drainage. Environmental Biology of Fihes. 59: 99-109.

Straskraba, M., \& Tundisi, J. G. (2000). Gerenciamento da Qualidade da Àgua de Represas. São Carlos. Editora oficina de textos, 280 p.

Surfer ${ }^{\circledR}$, version 9.11.947. Golden Software (2010). http://www.goldensoftware.com

Thornton, K. W., Kennedy, R. H., Carroll, J. H., \& et al., (1981). Reservoir Sedimentation and Water Quality-An Heuristic Mode1. In H.G. Stefan (ed), Proceedings Lf the Symposium on Surface Water Impoundments. Amer. Soc. Of Civil Eng., New York.

Weatherley, A. H. (1972). Growth and ecology of fish populations. Academic Press, London, 293 p. 